Historic, Archive Document

Do not assume content reflects current scientific knowledge, policies, or practices. 



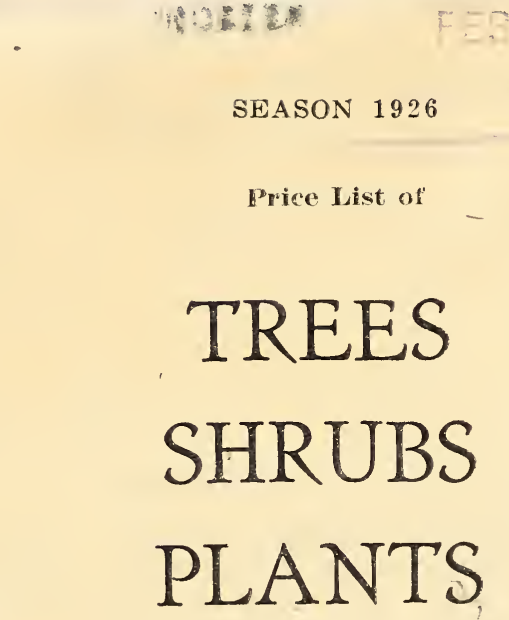

AEL ARIZONA GROWN

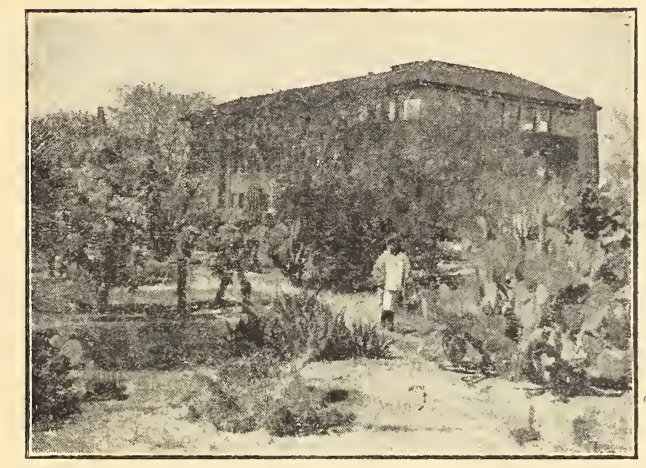

CAMPL'S SCENE, $\mathrm{U}$. of A.

\section{MONTHAN BROTHERS}

\section{Nurserymen}

P. O. Box 686

Phone 524-J

TUCSON, ARIZONA

Nurseries: La Cienega, Vail, Ariz.

Tucson Salesyard: Menlo Park.

Phoenix Salesyard: 1010 North Central Ave. 


\section{NOTICE TO CUSTOMERS}

TERMS-All orders sent out C. O. D. except to customers who have established credit with us.

All mail orders from correspondents unknown to us, and who desire goods sent C. O. D. must be accompanied by at least one-third cash.

REPLACEMIENTS-All the trees we sell have been passed as healthy by the State Inspectors, and we take great pains to deliver them in good condition. With anything like fair treatment on the part of the purchaser there is no reason why any tree should fail to grow. However, if for some unknown reason, a tree should fail to start and grow we will undertake to replace it at half-price; on condition that the tree be planted not later than March 15th, and that we are notified as to the failure of the tree before June 1st of the same season.

This replacement offer, however, does not apply where the trees do not receive fair treatment at the customer's hands, or where trees are shipped or handled by carriers or others beyond our control, and only applies on trees purchased at our list prices, and not on trees sold at wholesale rates or by special quotations.

GCARANTEE-We take every precaution to have each tree and plant true to label. If from any fault of ours a tree is not so, we will replace it free of charge, but it is to be understood that under no circumstances are we liable for more than the amount originally paid for such tree or plant. 


\section{A FEW :- THE PLANTING AND CARE of theaking souTHERN ARIZONA}

It is impossible in the space at our disposal to enter into a long discussion on the planting and care of trees, but we will simply mention a few of the details wherein the practice in this locality differs from that in other sections of the country, and wherein, as our experience shows us, inexperienced planters usually err.

(1) Deciduous trees and shrubs are those that shed their leaves and become dormant in winter. Such plants should be set out during the cold weather of January and February while they are dormant. They are dug up and transplanted with naked roots, and cannot safely be moved while in growth. Evergreen trees and shrubs, being usually moved with dirt around the roots, have a much longer planting season, and can be set out any time except during the extremely hot weather. A good time to plant hardy evergreens such as the Cypress is during October, and plants set out at this time will quickly get established and will make some growth during the winter months. The more tender evergreens, however, such as the Pepper tree, if planted at this time will run some risk from frost, and it is best to put off planting these until the heavy frosts are over about March.

(2) Where "Caliche" exists, tree holes are usually made four or five feet in diameter, and should be continued down until a softer stratum of "Caliche" is encountered. This will usually occur within four or five feet. This is done in order to provide drainage, which is absolutely necessary in these holes. When the hole is completed the drainage can be tested by filling the hole with water, and noting how fast it seeps away. Where drainage is very poor, dynamite is sometimes used to shake up the bottom of a hole, but is not usually necessary.

Use the best soil obtainable for filling the holes, rejecting all broken "caliche." It is not necessary, however, to haul "river bottom" or other special kinds of soil at great expense. Any fairly good soil that is handy will do just as well.

MANURE MUST NEVER BE USED in tree holes unless its use is thoroughly understood. Large numbers of trees are killed every year in this manner. Plain soil only should be used in the holes when planting, while fertilizers can be applied after the tree is established, by allowing them to seep down to the roots with the irrigation water.

No replacements will be made on trees where manure has been used in the tree holes.

(3) When your trees are delivered, if you are not ready to plant them at once, do not leave them in the bundles or bales, but immediately remove all packing materials from the roots and "heel then in" by digging a hole and burying" the roots in moist soil, covering well up onto the 
stems of the trees. In this wa:

will keep perfectly until you are ready $t$ them. Keep the roots of trees moist while handing, and expose them to the air as little as possible.

No replacements will be made on trees that have not been either planted or "heeled in" within twenty-four hours of delivery.

(4) When planting evergreen trees that are balled in cans do not try to remove the whole can, as you are more than likely to break the ball of dirt and kill the tree. With an ordinary can opener cut around and remove the bottom of the can, and then plant the tree with the sides of the can intact. After planting, should the sides of the can project above the soil, the part that does so can also be removed with the can opener. By handling the tree in this way there is no danger of breaking the ball of dirt, which would be fatal to the tree, and at the same time drainage is provided; while the part of the can left underground will soon rot away.

When trees are balled in burlap do not try to remove the burlap in planting, but simply place the tree in its proper position in the hole and pull in the dirt. The burlap will rot very quickly underground.

Balled trees should always be staked after planting to prevent damage from wind.

No replacements will be made on balled evergreen trees which are not handled in planting in accordance with the above directions.

We usually cut-back, ready for planting, all trees over a certain size, but in the case of small trees and shrubs to which this has not been done, care should be taken to cut them back at least one-third. This is very important, and applies particularly to Fruit trees.

No replacements will be made on Fruit trees or others which have not been cut back on planting.

(5) After a tree is planted and beiore it starts to grow, keep the soil damp, but do not irrigate it heavily every day, thus keeping the soil in a sodden condition.

See that each tree has a large deep basin around it for irrigation purposes, and never attempt to irrigate trees with a lawn sprinkler. A mulch or layer of straw, sawdust, leaves or some such material placec in each tree basin will prevent the soil baking in the sun after irrigation.

When you wish to irrigate turn on the water until you are sure that the ground is thoroughly wet down as far as the roots extend, and then withhold it until the top few inches of soil begin to show the need of it. When drainage exists there is no danger of applying too much water at one time, but it should not be applied too often, so that the ground remains in a sodden condition. 
Roughly speaking, trees should be irrigated at intervals varying from twice a week during the very hottest time of the year, to twice a month during the coolest. This, of course, varies somewhat with the nature of the soil and the kind of trees.

(6) Roses like a rather heavy, rich soil, and do best planted in the open, for although they appreciate shade during the hot months, they need all the sun possible during their blooming seasons in the Spring and Fall of the year. This does not mean, however, that climbing or other roses should be planted against a brick wall with a southern exposure, as in such a position the heat of the sun will surely burn them during the Summer. The pruning of roses when they are once established should never be neglected, and while dormant about January they should be cut back severely. When they cease blooming in the early Summer they should receive another pruning, but this time a very light one, and from then, until the cooler weather of the Fall arrives, their growth should be hindered by a somewhat stinted supply of water. This treatment will result in a profusion of bloom in the Fall of the year.

(7) About the end of September begin to prepare evergreens for frost by applying very little water, in order to harden the young wood resulting from the rapid growth that takes place in the Fall of the year.

As soon as cold weather has set in, begin to irrigate the evergreens again, and continue to do so throughout the winter. This treatment of evergreens will prevent injury by frost, as far as it is possible to do so.

\section{A SUGGESTION}

When "caliche" does not exist and there are no expensive holes to be dug, we suggest that it would be a highly profitable idea for the future, to plant a quantity of either Arizona Cypress or Eucalyptus trees (see page 9), provided one has sufficient unimproved land for the purpose. Planted in the form of groves, windbrakes or clumps, in the course of a few years these trees will make any place highly valuable and easily saleable. Small trees for this purpose grown in cans or pots are cheap, and since there is no shock in transplanting, such as larger trees undergo, will make a remarkably quick growth with sufficient irrigation. We will be glad to quote prices on trees for this purpose. 


\section{PRICE LIST OF TREES AND}

PLANTS SUITABLE FOR SOUTHERN ARIZONA

THE FOLLOWIG PRICES ARE FOR SINGLE TREES-SPECIAL PRICES ON QUANTITIES

SPECIMEY TREES, LARGER THAN THOSE LISTED BELOW, AT SPECIAL PRICES

QUOTATIONS BY SIZE OF TREES INSTEAD OF AGE MADE ON PEQUEST

\section{DHCHNOUS WREES}

THORNBER COTTONTOOD (COTTONLESS)Introduced by Profi. J. J. Thornber of the University $\mathrm{ot}^{\prime}$ Arizona. Is rery much superior to our native Cottonwood, growing more rapidly, and having a very much larger leaf and a clean silvery-white bark. It also sheds its leaves a month later in the Fall and comes out two weeks earlier in the Spring. This is the best tree to plant where an extremely quick-growing, large shade tree is desired.

2 to 3 years. $\$ 1.00$ to $\$ 2.00$ We have a limited number of Specimen trees of the Thornber Cottonwood, about 3 inches in diameter and 20 feet high. These trees will make a useful shade tree the very first season. $\$ 3.00$ each

TEXAS UMBRELLA-Well known popular shade tree. Dense, round, umbrella-shaped head, with dark green leaves.

2 to 3 years...

$75 \mathrm{c}$ to $\$ 1.50$

ARIZONA ASH-A native of this country and the only Ash that will grow here. One of the best trees for sireet planting, and is used for this purpose all over the Southwest.

2 to 3 years $75 \mathrm{c}$ to $\$ 1.50$

ARIZONA WALNUT-A large, spreading, native tree of dense foliage and of fairly rapid growth. Similar to the Black Walnut. Makes an excellent, hardy, long lived shade tree.

2 to 3 years..................................... 75 c to $\$ 1.50$

RUSSIAN MULBERRY-The best Mulberry for shade. A very hardy, quick-growing tree with large spreading head. Stands drought well. Fruit small and scanty.

2 to 3 years.

$75 \mathrm{c}$ to $\$ 1.50$

DOWNING NULBERRY-The best Mulberry for fruit. Grows rapidly and makes a good shade tree. Fruit large and plentiful.

2 to 3 years................................75c to $\$ 1.50$

FRUITLESS MULBERRY (KINGAN) - A guaranteed absolutely non-fruiting variety grafted on the Russian Mulberry. This tree, which originated with Judge S. L. Kingan of Tucson, has a particularly well shaped head. It blossoms in the Spring, but does not set fruit.

2 to 3 years...

$\$ 1.00$ to $\$ 2.00$

WEEPING RUSSIAN MULBERRY - A weeping tree of medium size and very graceful, with long slender branches drooping to the ground.

2 to 3 years.................................. $\$ 2.00$ to $\$ 3.00$ 
WEEPING WILLOW-A well-known, highly or, namental tree with drooping branches. Does well here with plenty of water.

2 to 3 years.................................

LOMBARDY POPLAR-A tall, spire-like tree with dense bright-green foliage and large leaves. Grows very rapidly, but requires plenty of water. 2 to 3 years.................................... $75 \mathrm{c}$ to $\$ 1.50$

BALM OF GILEAD-A poplar with a broad spreading head, large leaves and greenish bark. A very fine tree. 2 to 3 years..........75c to $\$ 1.50$

CAROLINA POPLAR-Has an upright pyramidal head and large, glossy, green leaves with white bark. A rapid grower under favorable conditions 2 to 3 years............................... $75 \mathrm{c}$ to $\$ 1.50$

CATALPA-Has a spreading head with large, heart-shaped leaves. Bears immense clusters of white and blue flowers freely in Spring.

2 to 3 years............................... $75 \mathrm{c}$ to $\$ 1.50$

BLACK LOCUST-A very hardy, quick-growing tiee with spreading thorny branches, bearing white flowers in Spring.

2 to 3 years......................................

HONEY LOCUST-A rapid-growing, ornamental tree with a loose, open head and acacia-like foliage. Is very graceful and extremely droughtresistant.

2 to 3 years.......................................... to $\$ 1.50$

AILANTHUS (Tree of Heaven) - A purely ornamental tree with long, fern-like leaves. Grows quickly. 2 to 3 years........................75c to $\$ 1.50$

ELM (Chinese) - A new tree that has been growing for the last four years on the University campus. Has the appearance and habit of the American Elm, but is a rapid grower.

2 to 3 years........................... $\$ 1.00$ to $\$ 2.00$

ELDER (Native Mexican)-Very popular. Grows all Winter and is green by Christmas. Flowers in Spring. Can be trained as either tree or shrub. 2 to 3 years........................ 75 c to $\$ 1.50$

\section{DECIDUOUS SHRUBS}

POMEGRANATE (Fruiting)_Very popular for hedges, bears excellent fruit.

Per hundred.......................... $\$ 10.00$ to $\$ 20.00$

POMEGRANATE (Flowering) - A handsome shrub with shining green leaves and large double red or variegated flowers...................... $75 \mathrm{c}$ to $\$ 1.00$

TAMARISK-Very hardy. Has fine feathery foliage tipped with large spikes of small pink flowers. Will stand considerable alkali. Is used for hedges or screens, and is very effective grown in clumps. Can be headed up as a tree if desired. $.75 \mathrm{c}$ to $\$ 1.00$

ALTHEA (Rose of Sharon) - A pretty, very freeflowering shrub blooming during the hot weather when flowers are scarce.

Several colors

$.75 \mathrm{c}$ to $\$ 1.00$

SPIREA (Bridal Wreath)-Medium-sized, grace, ful, white-flowering shrub. Flowers profusely in the Spring................................. $\mathrm{c}$ c to $\$ 1.00$

LILAC-Can be grown successfully in this climate, but requires considerable care and attention and prefers some shade during the hot weather. 
LEMON VERBENA-An old-fashioned shrub, grown chiefly for the fragrance of its foliage. $.75 \mathrm{c}$ to $\$ 1.00$

\section{EVERGREEN TREES}

PEPPER TREE-One of the most popular evergreen trees throughout the Southwest wherever the frost is not too severe. The drooping, feathery toliage is particularly graceful. This tree is very sensitive to overwatering, especially when newly planted. Grown in cans.

2 and 3 years..................................... $55 \mathrm{c}$ to $\$ 1.50$

ARIZONA CYPRESS-A splendid native ornamental tree of pyramidal habit. Bluish-green foli, age. A good grower and very hardy. When once established this tree will exist without irrigation, on our rainfall alone, although of course under such conditions the growth will be slow, Grow 1 in cans, 2 and 3 years............75c to $\$ 2.00$ Balled, 3 to 5 feet.................... $\$ 3.00$ to $\$ 5.00$ The chree kinds of Cypress trees listed here deserve planting extensively. They are among the finest of ornamental evergreens and are never damaged by frost. Their style of foliage contrasts well with other trees, and they never fail to attract attention wherever planted. The campus of the University of Arizona has been planted exten? sively to these trees during the last few years, owing to their being so well adapted to the conditions prevailing there.

MONTEREY CYPRESS-The well-known Californian Cypress with dense, dark green foliage. Contrasts well with the Arizona Cypress.

Grown in cans, 2 and 3 years......... $75 \mathrm{c}$ to $\$ 2.00$

ITALIAN CYPRESS (Pillar Cypress)-A tall, tapering form with branches growing parallel with the trunk.

Grown in cans, 2 and 3 years........... $75 \mathrm{c}$ to $\$ 2.00$ Balled, 3 to 5 feet......................... $\$ 3.00$ to $\$ 5.00$

ARBOR VITAE (Chinese)-A low, bushy, compact, symmetrical tree of pyramidal shape. An excellent ornamental for a small yard or for informal planting. Grown in cans.

2 and 3 years.

$75 c$ to $\$ 1.50$

Balled, 2 to 3 feet.

$\$ 2.50$ to $\$ 4.00$

CASUARINA (Beefwood) - A rapid-growing, tall, upright tree with drooping branches, bearing dark green, needle-like leaves. A very handsome ornamental tree, growing well in any kind of soil.

Grown in cans, 2 and 3 years.......... 75 c to $\$ 1.50$

EUCALYPTUS-We grow two varieties of these well-known trees. (1) E. Rudis or the Desert Gum. (2) E. Rostrata or the Red Gum. These are the two best varieties for this climate.

Grown in cans, 2 and 3 years........ $75 \mathrm{c}$ to $\$ 1.50$

WEEPING PITTOSPORUM-A very handsome, medium-sized tree with drooping branches. Quite hardy. Grown in cans, 2 and 3 years.

$75 \mathrm{c}$ to $\$ 1.50$

STERCULIA (Bottle Tree or Australian Poplar) Of upright tapering habit. Leaves change shape continually. An excellent tree for street planting.

2 and 3 years $75 \mathrm{c}$ to $\$ 1.50$ 
PALO VERDE (Bagote)-A curious native tree with bright green bark and feathery branches. Is covered with yellow flowers in the spring.

Grown in cans, 2 and 3 years..........75c to $\$ 1.50$

LOQUAT-A low-growing Japanese fruit tree with large, rough, glaucous leaves.

Grown in cans, 2 and 3 years........ $\$ 1.50$ to $\$ 2.00$

\section{EVERGREEN SHRUBS}

OLEANDER-Most popular evergreen flowering shrub. We grow the two best varieties: double pink and double-white. Balled...... $\$ 1.00$ to $\$ 2.50$

JASMINE (Primulinum) -Dark green drooping branches covered with bright yellow flowers. A semi-trailing plant that is handsome all the year round..................................... $75 \mathrm{c}$ to $\$ 1.50$

CALIFORNIA PRIVET-The most common evergreen hedge plant.

Per 100, Bare Roots............... $\$ 10.00$ and $\$ 15.00$ Specimens (balled) ......................... $\$ 1.00$ to $\$ 1.50$

JAPANESE PRIVET-Has a larger leaf than the California Privet, and is more persistently evergreen. Can be used either for a hedge or as a tree.

In flats, per $100 \ldots \ldots \ldots \ldots$ Specimens (Balled) ........................... $\$ 1.50$ to $\$ 2.00$

EUONYMUS (Japonicus)-Very effective as a specimen shrub. Stands trimming wel? and makes a grand hedge plant.

Grown in cans................................75c to $\$ 1.50$

PITTOSPORUM (tobira)-A low-growing ornamental shrub with dark green leaves.

Grown in cans....................................75c to $\$ 1.50$

BURNING BUSH (Crataegus pyracantha)-A thick, thorny shrub with small glossy leaves. Bears white flowers, followed by red berries which persist all winter.

Grown in cans.................................75c to $\$ 1.50$

COTONEASTER PANOSA-A very attractive shrub, bearing scarlet berries all winter.

Grown in cans.....................................75c to $\$ 1.50$

EVERGREEN TAMARISK (Athel)-A new introduction from Algiers. Grayish-green foliage resembling somewhat the Arizona Cypress. Grows extremely rapidly, and can be used either as a tree or a shrub. Grown in cans........75c to $\$ 1.50$ Cuttings........................................ $\$ 3.00$ per 100

SPANISH BROOM-Well known yellow-flowering shrub. Very resistant to drought.

Grown in cans..................................75c to $\$ 1.50$

LAVENDER-For low hedges. Useful for edging walks. Per dozen..........................................\$1.50

\section{PALMS}

CALIFORNIA FAN PALM (Washingtonia Filifera) - The only hardy, large-growing Fan Palm for this locality. A rapid grower. Can be used for street-planting, if desired.

Balled, 2 to 3 years........................ $\$ 1.50$ to $\$ 2.5 n$ Extra large Specimens. Prices on application.

ORNAMENTAL DATE PALM (Phoenix Canariensis)-One of the handsomest of all Palms with dark green pinnate leaves. Is not quite so hardy as the Fan Palm and grows somewhat slower. Makes an excellent tub plant.

Balled, 2 to 4 years $\$ 2.00$ to $\$ 3.50$ Extra large Specimens. Prices on application. 


\section{ROSES}

We have small stocks of many other varieties in addition to those listed below. We have probably got the particular variety you are looking for. If you wish us to make a selection of varieties for you we will do our best to satisfy you.

$$
\begin{aligned}
& 1 \text { year, } 50 \mathrm{c} \text { each; } \$ 4.50 \text { per } 10 \\
& 2 \text { year, } 75 \mathrm{c} \text { each; } \$ 6.50 \text { per } 10
\end{aligned}
$$

RED-

American Beauty (rosy-crimson).

Crimson Queen (dark crimson).

Ecarlate (scarlet red).

Eugene E. Marlitt, (carmine-scarlet).

George Dickson (dark crimson).

Gruss an Teplitz (bright crimson).

His Majesty (deep-crimson).

J. B. Clark (deep-scarlet).

Mrs. A. R. Waddell (rosy-scarlet).

Red Radiance (crimson-scarlet).

Ulrich Brunner (cherry-red).

\section{PINK-}

F. R. Patzer (buff-pink).

George Ahrends (clear-pink).

La Detroit (shell-pink).

La France (silvery-pink).

Mile. Cecile Brunner (salmon-pink).

Mme. Caroline Testout (clear-pink).

Mrs. Chas. Bell (shell-pink).

Ophelia (salmon-flesh).

Radiance (rosy-carmine).

Wellesley (bright pink).

\section{WHITE-}

Bessie Brown (creamy-white).

Frau Carl Druschki (pure white).

Kaiserin A. V. (ivory-white).

White La France (pearl-white).

\section{YELLOW-}

Etoile de Lyon (sulphur-yellow).

Isabelle Sprunt (bright-yellow).

Lady Hillingdon (golden-yellow).

Souv. de Pierre Notting (apricot-yellow).

Sunburst (cadmium-yellow).

\section{CLIMBING ROSES}

$75 \mathrm{c}$ each except where noted.

Cherokee (double white).

Christine Wright (pink).

Climb. American Beauty (rosy-crimson).

Climb. Cecile Brunner (salmon-pink).

Climb. Gruss an Teplitz (bright crimson).

Climb. Helen Gould (carmine).

Climb. Kaiserin A. V. (ivory-white).

Climb. Papa Gontier (deep crimson).

Climb. Souv. de Wooton (crimson).

Climb. White Cochet (cream-white).

Lamarque (pure white).

Marechal Neil (golden-yellow), $\$ 1.00$ each. 


\section{FRUIT TREES}

In planting fruit trees in Southern Arizona the choice of varieties is very important. Many of the leading varieties in other parts of the country fail to fruit here even when the tree itself stands the climate. We grow our own trees from the roots up and bud or graft them from bearing trees.

PRICES-1 yr., 3-4 ft., 50c each; $\$ 4.50$ for 10 ; $\$ 35.00$ per 100 .

2 yr., 4-6 ft., $75 \mathrm{c}$ ea.; $\$ 6.50$ for $10 ; \$ 50.00$ per 100 .

The rate per 10 and rate per 100 apply to trees of one kind only.

Extra heavy selected trees..................\$1.00 each

PEACH-Alexander, Foster, Champion, Elberta,

Lovell, Early Crawford, Late Crawford, Salway,

Krummel, Phillips Cling, W. Heath Cling.

APRICOT-Newcastle, Royal, Tilton, Moorpark.

PLUM-Burbank, Wickson, Satsuma, Damson,

Santa Rosa, Beauty.

NECTARINE-Advance.

ALMOND-Texas Prolific.

PEAR-Bartlett, Kieffer, Flemish Beauty, Winter Bartlett.

APPLE-Gravenstein, Jonathan, W. W. Pearmain,

Winesap, Transcendent Crab.

QUINCE-Champion.

FIG-Erown Turkey, Black Mission, White Adriatic.

POMEGRANATE-Wonderful, Papershell.

OLIVE-Mission. $\$ 1.25$ each; $\$ 10.00$ for $\$ 10$.

GRAPES-Thompson's Seedless, Malaga, Muscat,

Mission, Tokay, Black Morocco, Concord.

1 year...25c each; $\$ 2.00$ per $10 ; \$ 10.00$ per 100

BLACKBERRIES...............15c each; \$1.25 per 10 DEWBERRIES....................20 each; $\$ 1.50$ per 10 STRAWBERRIES (Everbearing)

$75 \mathrm{c}$ per doz.; $\$ 2.50$ per $100 ; \$ 15.00$ per 1000

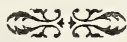

\section{WHY NOT?}

Why not buy Arizona-grown trees for Arizona planting? Is it not reasonable to suppose that a tree that has been raised in Arizona, and is handled direct from the nursery to the planter, is more likely to succeed under any circumstances, than one raised in some other locality that has been shipped in by freight and handled by various dealers? Why buy shipped-in trees from some traveling salesman when you have a HomeNursery right at your door, where you not only get the benefit of 16 years experience of treegrowing in Tucsor, but you can see in advance what you are getting for your money and select your own trees? 


\section{CLIMBING PIANTS}

VIRGINIA CREEPER-The hardiest and most rapid growing deciduous climber for our climate $50 \mathrm{c}$

BOSTON IVY-Differs from the Virginia Creeper in its habit of clinging closely to a wall or other flat surface. Does best in partial shade. Deciduous $50 \mathrm{c}$ to $75 \mathrm{c}$

TRUMPET VINE-A strong-growing, deciduous vine with scarlet trumpet-shaped flowers.....50

HONEYSUCKLE (Chinese)-Vigorous evergreen climber. Flowers white, changing to yellow. Very fragrant.................................. $50 \mathrm{c}$ to $75 \mathrm{c}$

ENGLISH IVY-Well-known evergreen climber with dark, glossy, green leaves. Will cling to a wall without support. Rather slow-growing to begin with. Must have shade.........50 c to $75 \mathrm{c}$

ANTIGONON LEPTOPUS (Mountain Rose)-A climber from Mexico flowering all summer with racemes of rose-colored flowers two feet long. $.50 \mathrm{c}$ to $75 \mathrm{c}$

BIGNONIA TWEEDIANA (Evergreen Trumpet Vine)-Will cling to any rough surface. Flowers orange-yellow. $50 \mathrm{c}$ to $75 \mathrm{c}$

\section{BEDDING PLANTS (at Proper Seasons)}

Potted, $75 \mathrm{c}$ per dozen

Calendula

Hollyhock

Pansy

Violet

\section{Petunia}

Shasta Daisy

Snapdragon

Verbena

Carnation, $\$ 1.50$ per doz.

Chrysanthemum, $\$ 1.50$ per doz.

Geranium, $\$ 2.00$ per doz.

Canna, 20c each; $\$ 2.00$ per doz.

Dahlia, $25 \mathrm{c}$ each; $\$ 2.50$ per doz.

\section{VEGICABLF PLANTS (at Ploper Seasons)}

Asparagus roots, $50 \mathrm{c}$ per doz.; $\$ 2.00$ per 100 .

Pepper (Chile), 50c per doz.; $\$ 1.50$ per 100 : $\$ 5.00$ per 1000 .

Pepper (Bull nose), 75c per doz.

Tomatoes, 50c per doz.; $\$ 1.50$ per $100 ; \$ 6.00$ per 1000 .

Tomatoes, potted, $75 \mathrm{c}$ per doz.

\section{HOUSE PIANTS}

We can usualiy supply a variety of choice potted plants suitable for house decoration.

Description and prices on application.

\section{MISCEILANEOUS PLANTS}

Pampas Grass. $\$ 1.00$

Yuccas (several varieties) balled.... $\$ 1.00$ to $\$ 2.50$ Lippia repens (for lawns) per sack...............\$3.00

(One sack will plant about 500 square feet). 